\title{
PENINGKATAN KOMPETENSI PEDAGOGIK GURU IPA BERBASIS PENDIDIKAN AGAMA ISLAM MELALUI ALAT PERAGA IPA KONTEKSTUAL DI MI KECAMATAN NGABLAK, MAGELANG
}

\author{
Budiyono Saputro \\ Sekolah Tinggi Agama Islam Negeri Salatiga \\ budiyono_saputro@yahoo.com
}

\begin{abstract}
The aim of this study is to determine the improvement of pedagogic competence science teacher based of Islamic education at Isalamic elementary School through the implementation of training management model contextual equipment science with the use of the natural surroundings. This research is a quantitative study. Instrument research was a questionnaire, interview sheet, pretest, posttest, and the observation sheet. The results of this study was pedagogic competence science teacher based Islamic Education at Islamic elementary School at Magelang regency, Ngablak subistrict is effective increased through the implementation of training management model contextual equipment science with the use of the natural surroundings as His grace revealed to man. Increased the ability of science teachers can be seen from the results of the pre-posttest through paired test significance $0.000<0.05$, the observation capabilities of teachers used contextual equipment science for science teacher based of Islamic education in the post-training schools was competent results.
\end{abstract}

Key words: Pedagogic competence, management training, natural surroundings

\begin{abstract}
Abstrak
Penelitian ini bertujuan untuk mengetabui peningkatan kompetensi pedagogik guru IPA MI berbasis Pendidikan Agama Islam melalui penerapan model manajemen pelatihan alat peraga IPA kontekstual dengan pemanfaatan alam sekitar. Jenis penelitian ini adalah penelitian kuantitatif. Instrumen pengambilan data adalah angket, lembar interview, soal pretes, postes, dan lembar observasi. Hasil penelitian menunjukkan
\end{abstract}


kompetensi pedagogik guru IPA MI berbasis Pendidikan Agama Islam se-Kecamatan Ngablak Kabupaten Magelang efektif dapat meningkat melalui penerapan model manajemen pelatihan alat peraga IPA konteskstual melalui pemanfaatan alam sekitar sebagai rabmatNya pada manusia. Peningkatan kemampuan guru IPA dapat dilihat dari hasil pre-postes melalui paired t test signifikansi $0,000<0,05$, pengamatan kemampuan penggunaan alat peraga IPA guru IPA MI berbasis Pendidikan Agama Islam pascapelatihan di sekolah masing-masing dengan hasil kompeten.

Kata kunci: Kompetensi pedagogik, manajemen latihan, pemanfaatan alam

\section{Pendahuluan}

Pembelajaran IPA di MI secara ideal dilapangan diampu oleh guru kelas alumni PGMI. Faktual dilapangan guru IPA MI se-Kecamatan Ngablak dari 7 (tujuh) MI hanya 1(satu) MI saja yang memiliki guru IPA alumni PGMI. Tujuh MI lainnya pembelajaran IPA diampu oleh guru berbasis Pendidikan Agama Islam. Hal tersebut merupakan masalah serius yang harus ditangani untuk menghindari miskonsepsi dalam pembelajaran IPA. Satu diantara solusi bagi guru IPA MI yang berbasis Pendidikan Agama Islam adalah dengan pelatihan alat peraga IPA secara kontekstual dengan pemanfaatan alam sekitar, agar pelatihan dapat maksimal perlu diterapkan model manajemen pelatihan. Dengan demikian peningkatan kompetensi pedagogik guru IPA MI berbasik Pendidikan Agama Islam dalam pembelajaran IPA dapat meningkat.

Alat peraga merupakan salah satu faktor keberhasilan dalam proses belajar mengajar. Manfaat alat peraga yang lain adalah salah satu metode yang variatif yang dapat meransang minat siswa sehingga tetap dapat berkonsentrasi pada pelajaran. Ian (2010: 1) menyatakan "alat bantu pembelajaran lebih sering disebut alat peraga karena berfungsi untuk membantu dan meragakan sesuatu dalam proses pendidikan pengajaran" .Sudjana (2002: 99) "alat peraga dalam mengajar memegang peranan penting sebagai alat bantu untuk menciptakan proses belajar mengajar yang efektif". Nuryati (2014: 1) "pelajaran IPA membutuhkan kombinasi dalam proses belajar 
mengajar dengan menggunakan alat peraga yang sangat sederhana yang sesuai dengan daya pikir anak, maka pelajaran apapun dengan mudah dipahaminya..

Proses belajar mengajar Ilmu Pengetahuan Alam (IPA) pada tingkat Madrasah Ibtidaiyah (MI) bertujuan agar siswa memahami pengertian-pengertian dasar IPA dan saling berkaitan dengan kehidupan sehari-hari, memahami lingkungan alam. Berdasarkan pada tujuan pengajaran IPA tersebut, maka dalam menyampaikan materi IPA diperlukan alat peraga. Inovasi penggunaan alat peraga sangat penting dalam menentukan keberhasilan siswa dalam memahami materi IPA. Penggunaan alat peraga hendaknya disesuaikan dengan kondisi lingkungan sekolah dengan kata lain secara kontekstual melalui pemanfaatan alam sekitar, dengan demikian siswa semakin dekat dengan lingkungan dan tidak asing dengan pemahaman yang nyata. Kondisi lingkungan dan potensi alam kecamatan Ngablak sangat berpotensi untuk pemanfaatan alat peraga dalam pembelajaran IPA khususnya pada tingkat MI.

Berdasarkan studi pendahuluan yang peneliti lakukan diperoleh temuan sebagai berikut: (1) latar belakang guru IPA didominasi Sarjana Pendidikan Agama Islam, (2) guru IPA belum memanfaatkan alat peraga, hal tersebut dikarenakan MI belum memiliki alat peraga sesuai kebutuhan, (3) guru IPA tidak mengetahui cara penggunaan dan pemanfaatan alat peraga, (4) metode pembelajaran IPA yang digunakan konvensional yaitu ceramah, hal ini membuat siswa merasa bosan, (5) guru IPA belum memanfaatkan alam sekitar dan lingkungan untuk pembelajaran IPA berbasis kontekstual. Hal tersebut dikarenakan guru merasa tidak kompeten dan menghindari miskonsepsi pembelajaran IPA, (6) sebagian besar MI belum memiliki alat peraga untuk pembelajaran IPA. Kondisi guru IPA yang demikian sangat memprihatinkan. Pelatihan merupakan upaya untuk peningkatan kompetensi pedagogik guru IPA dalam pemanfatan alat peraga. Pelatihan dapat berhasil dengan memperhatikan manajemen. Model manajemen pelatihan alat peraga ini menggunakan konsep model manajemen pelatihan IPA terpadu hasil pengembangan oleh Saputro (2013: 143). Berdasarkan latar belakang di atas, maka dapat dirumuskan masalah penelitian sebagai berikut: (1) bagaimanakah kondisi nyata pemanfaatan alat peraga secara 
kontekstual pada guru IPA MI berbasis Pendidikan Agama Islam melalui pemanfaatan alam sekitar di Kec. Ngablak Kab. Magelang?, (2) bagaimanakah cara optimalisasi pemanfaatan alat peraga IPA secara kontekstual dengan pemanfaatan alam sekitar bagi guru IPA MI berbasis Pendidikan Agama Islam di Kec. Ngablak?, (3) apakah model manajemen pelatihan alat peraga secara kontekstual efektif dapat meningkatkan kompetensi pedagogik guru IPA MI berbasis Pendidikan Agama Islam di Kecamatan Ngablak Kabupaten Magelang?

\section{Kompetensi Pedagogik Guru IPA MI}

Hasil penelitian yang dilakukan oleh Moeini (2008: 9) bahwa pelatihan bagi guru dapat meningkatkan profesionalisme dalam pekerjaannya. Osunde and Omoruyi (2004: 409) melakukan penelitian analisis hasil yang diperoleh menunjukkan bahwa program ini cukup efektif dalam meningkatkan keterampilan dan pengetahuan peserta. Hanrahmawan (2010: 90) manajemen pelatihan yang dilakukan di BLKI Makasar telah sesuai dengan analisis kebutuhan, namun evaluasi hanya sebatas bahan koreksi dalam perbaikan manajemen saja. Susanti, dkk (2012: 55) ukuran keberhasilan penyelenggaraan pendidikan dan pelatihan dalam rancangan Management By Objectives (MBO) dan perspektif Balanced Scorecard ditentukan dengan tercapainya target kinerja individu peserta pelatihan, dana, Standard Operational Procedure (SOP), SDM penyelenggara, teknologi dan inovasi. Danso, dkk (2012: 100) efektifitas pelatihan dapat ditunjukkan dari memadainya durasi waktu pelatihan untuk melakukan diskusi dan tugas, kesesuaian handout, soft copy, CD dan presentasi slide, nara sumber. Relevansi pelatihan dapat ditunjukkan dengan manfaat dari pelatihan bagi peserta, kemampuan dan sikap terhadap pekerjaan.

Perbedaan yang peneliti lakukan sekarang adalah: pertama, peneliti berfokus pada guru IPA MI yang memiliki basis keilmuan Pendidikan Agama Islam namun memiliki tugas mengajar guru kelas mata pelajaran IPA. Kedua, model manajemen pelatihan pemanfaatan alat peraga IPA secara kontekstual adaptasi hasil pengembangan Saputro (2013: 143) dengan tahapan sebagai berikut: perencanaan, pelaksanaan, monitoring dan evaluasi serta tindak lanjut pasca 
pelatihan (perencanaan, pelaksanaan dan penilaian dan pelaporan). Ketiga, Efektifitas dari model manajemen pelatihan dalam rangka peningkatan kompetensi pedagogik guru IPA MI berbasis Pendidikan Agama Islam dalam pemanfaatan alat peraga secara kontekstual.

Guru IPA MI idealnya adalah kompeten dalam menyampaikan pembelajaran IPA di kelas. Kompetensi menurut Wibowo (2010: 324) "adalah suatu kemampuan untuk melaksanakan atau melakukan suatu pekerjaan atau tugas yang dilandasi atas keterampilan dan pengetahuan serta didukung oleh sikap kerja yang dituntut oleh pekerjaan tersebut". Spencer and Spenser dalam Uno (2010: 62) mendifinisikan "kompetensi adalah kemampuan sebagai karakteristik yang menonjol dari seseorang individu yang berhubungan dengan kinerja efektif dan atau superior dalam suatu pekerjaan atau situasi”. Sedangkan definisi kompetensi menurut Sedarmayanti (2010: 126) "kompetensi diartikan sebagai kecakapan, ketrampilan dan kemampuan". Menurut Kunandar (2011: 55) "kompetensi guru adalah seperangkat penguasaan kemampuan yang harus ada dalam diri guru agar dapat mewujudkan kinerjanya secara tepat dan efektif". Saud (2009: 45) "kompetensi dipandang sebagai pilarnya atau teras kinerja dari suatu profesi".

Mahmuddin (2008: 1) Kompetensi pedagogik yang antara lain adalah kemampuan pemahaman tentang peserta didik secara mendalam dan penyelenggaraan pembelajaran yang mendidik. Kompetensi pedagogik guru kelas MI/SD dalam Undang-Undang Guru dan Dosen RI No.14 Tahun 2005 adalah: (1) menguasai karakteristik peserta didik dari aspek fisik, moral, sosial, kultural, emosional dan intelektual, (2) menguasai teori belajar dan prinsip-prinsip pembelajaran yang mendidik, (3) mengembangkan kurikulum yang terkait dengan mata pelajaran/ bidang pengembangan yang diampu, (4) menyelenggarakan pembelajaran yang mendidik, (5) memanfaatkan teknologi informasi dan komunikasi untuk kepentingan pembelajaran, (6) memfasilitasi pengembangan potensi peserta didik untuk mngaktualisasikan berbagai potensi yang dimiliki, (7) berkomunikasi secara efektif, empatik dan santun dengan peserta didik, (8) menyelenggarakan penilaian dan evaluasi proses dan hasil belajar, (9) memanfaatkan hasil penilaian dan evaluasi untuk 
kepentingan pembelajaran, (10) melakukan tindakan reflektif untuk peningkatan kualitas pembelajaran.

Berdasarkan uraian di atas tentang kompetensi pedagogik guru kelas MI/SD, maka penulis fokus pada kompetensi point 2 dengan isi menerapkan berbagai pendekatan, strategi, metode dan teknik pembelajaran yang mendidik secara kreatif dalam lima mata pelajaran SD/MI. Mata pelajaran yang penulis angkat adalah IPA.

\section{Wahyu Kawniyyab sebagai Dasar Pembelajaran IPA}

Proses belajar mengajar IPA pada tingkat MI/SD bertujuan agar siswa memahami pengertian-pengertian dasar IPA dan saling berkaitan dengan kehidupan sehari-hari, yaitu memahami lingkungan alam. Wahyu Allah dapat terbagi dua yaitu qawliyyah (terucap) dan kawniyyah (alam terhampar). Alam diciptakan oleh Allah SWT dapat dimanfaatkan sebagai sumber pembelajaran IPA sebagaimana difirmankan Allah SWT dalam surat al-Jatsiyah ayat 13:

Dan dia telah menundukkan untukmu apa yang di langit dan apa yang di bumi semuanya, (sebagai rahmat) daripada-Nya. Sesungguhnya pada yang demikian itu benar-benar terdapat tanda-tanda (kekuasaan Allah) bagi kaum yang berfikir.

Berdasarkan ayat di atas, bahwa manusia telah diberikan kelebihan sebagai makhluk hidup yang sempurna dengan akal budinya oleh Allah. Dengan akal budi dan pikirannya, guru dapat menjadikan pembelajaran lebih bermakna. Keaktifan dan kreativitas diperlukan untuk melaksanakan pembelajaran secara kontekstual dalam memanfaatkan alam sebagai alat peraga IPA, sehingga dengan demikian siswa semakin dekat dengan lingkungan dan dengan pemahaman yang nyata. Mempelajari IPA merupakan kegiatan yang ilmiah dan dapat mempertebal keimanan seseorang kepada Allah SWT memelaui wahyu kawniyyah, yaitu alam ciptaan Allah yang terhampar di sekeliling manusia dari benda paling kecil sampai benda yang besar.

Pembelajaran IPA memerlukan keterampilan proses karena dalam pembelajaran IPA dilakukan secara logis, sistematis dan empiris. Keterkaitan alam, lingkungan sekitar dan alat peraga IPA kontekstual sebagai rujukan dalam pembelajaran IPA membuat orang 
yang mempelajari IPA semakin memiliki dan memperbesar rasa keagungan kepada Allah SWT. Sehingga dengan demikian mempelajari IPA sejalan dengan pandangan ilmuwan dengan ajaran agama. Alam yang merupakan ciptaan Allah SWT dapat dijadikan sumber belajar yang memiliki nilai positif dalam implementasi pembelajaran IPA. Alam sebagai sumber belajar dapat dijadikan rujukan dalam mendesain pembelajaran IPA secara kontekstual melalui pemanfaatan alat peraga.

Beberapa alat peraga IPA secara kontekstual dari alam sekitar adalah:

1. Magnet dari besi atau paku. Alat dan bahan: paku bekas, magnet, serbuk besi yang dibuat sendiri dari pasir. Cara Kerja: siapkan magnet dan paku bekas, gosok-gosokkan paku bekas tersebut pada magnet hingga paku bekas tersebut dapat menarik paku atau serbuk besi. Setelah paku bekas dapat menarik serbuk besi bearti paku bekas tersebut telah menjadi magnet.

2. Herbarium dan Insektarium. Alat dan bahan: dua buah bilah bambu yang dianyam ukuran 40 x $40 \mathrm{~cm}$, Kertas koran bekas/ kertas payung, Tali rafia, Kertas karton manila ukuran 40 x 30 $\mathrm{cm}$, Kertas minyak ukuran $40 \times 30 \mathrm{~cm}$. Cara kerja: siapkan alat dan bahan yang diperlukan, carilah tumbuhan herba di sekitarmu lengkap dari akar batang daun, bunga dan biji, bersihkan kotorannya, sering anginkan, siapkan engkek yang dilapisi kertas koran/payung, letakkan dengan rapi tumbuhan herba tersebut, kemudian tutup dengan kertas koran dan bilah bambu yang dianyam, katlah dengan hati-hati menggunakan tali rafia engkek tersebut, jemur di terik matahari selama kurang lebih 2 minggu, setelah kering ambil herba kering tersebut kemudian tempelkan di kertas manila yang telah disiapkan, tutuplah dengan kertas minyak dan simpan di tempat yang kering.

3. Koleksi batuan. Alat dan bahan: papan kayu ukuran 20 x 30 $\mathrm{cm}$, lem, alat tulis. Cara kerja: carilah macam dan jenis batuan yang ada di sekitar anda, amati dan identifikasi masing-masing batuan yang anda temukan, tempelkan pada papan yang telah disiapkan, berilah label pada batuan yang anda temukan. 
4. Gerhana matahari dan bulan. Alat dan bahan: tiga buah bola bekas yang ukurannya berbeda, cat merah putih dan biru, kabel, bolam lampu kecil, bambu yang sudah dibentuk sebagai tiang penyangga bola, kuas. Cara kerja: disiapkan tiga buah bola yang berbeda ukuran, cat ketiga bola tersebut. Warna merah untuk bola yang paling besar sebagai matahari, warna putih untuk bulan, dan warna biru untuk bumi, susun ketiga bola tersebut secara berurutan dengan bantuan tiang yang terbuat dari bambu, atur ketiga bola tersebut supaya dapat digerakkan, tambahkan lampu pada bola warna merah agar jika dinyalakan dapat dilakukan simulasi gerhana bulan dan matahari.

5. Bumi dan lapisannya. Alat dan bahan: bola bekas, cat merah putih dan biru, kuas dan gabus keras. Cara kerja: disiapkan bola bekas, belahlah bola tersebut jadi dua, masing-masing belahan bola diberi gabus dan dicat, gambarlah lapisan bumi pada gabus keras tersebut, gambar pulau pada kulit luar bola tersebut.

\section{Konsep Manajemen Pendidikan dan Pelatihan}

Terry (1977: 4) "management is a distinct process consisting of planning, organizing, actuating, and controlling, performed to determine and accomplish stated objectives by the use of human beings and other resources". (Manajemen merupakan sebuah proses yang khas, yang terdiri dari tindakan-tindakan: perencanaan, pengorganisasian, penggiatan dan pengawasan, yang dilakukan untuk menentukan serta mencapai sasaran-sasaran yang telah ditetapkan melalui pemanfaatan sumber daya manusia dan sumber-sumber lain). Mulyono (2009: 18) menyatakan "manajemen adalah sebuah proses yang khas yang terdiri dari perencanaan, pengorganisasian, penggerakan dan pengawasan serta evaluasi yang dilakukan pihak pengelola organisasi untuk mencapai tujuan bersama dengan memberdayakan sumber daya lainnya". Menurut Fattah (2009: 1) "manajemen diartikan sebagai proses merencana, mengorganisasi, memimpin dan mengendalikan upaya organisasi dengan segala aspeknya agar tujuan organisasi tercapai secara efektif dan efesien”. Kamil (2010: 16) "secara manajerial, fungsi-fungsi organizer pelatihan adalah merencanakan, melaksanakan, dan mengevaluasi pelatihan”. Pelatihan perlu dikelola agar berhasil dalam penyelenggaraan- 
nya. Menurut Mujiman (2009: v) manajemen pelatihan adalah "pengelolaan program pelatihan, yang menyangkut aspek pengidentifikasian kebutuban pelatiban, perencanaan disain pelatihan, penetapan metodologi pelatiban, penyusunan bahan pelatihan, pelaksanaan pelatihan, evaluasi pelatihan, dan penetapan tindak lanjut pelatiban". Untuk mencapai tujuan dari manajemen pelatiban yang dilakukan, diperlukan sarana-sarana atau unsur-unsur manajemen.

Penulis berpendapat bahwa manajemen pelatihan memerlukan proses dan tahapan untuk mencapai tujuan. Adapun tahapan pelatihan seperti gambar 1 .

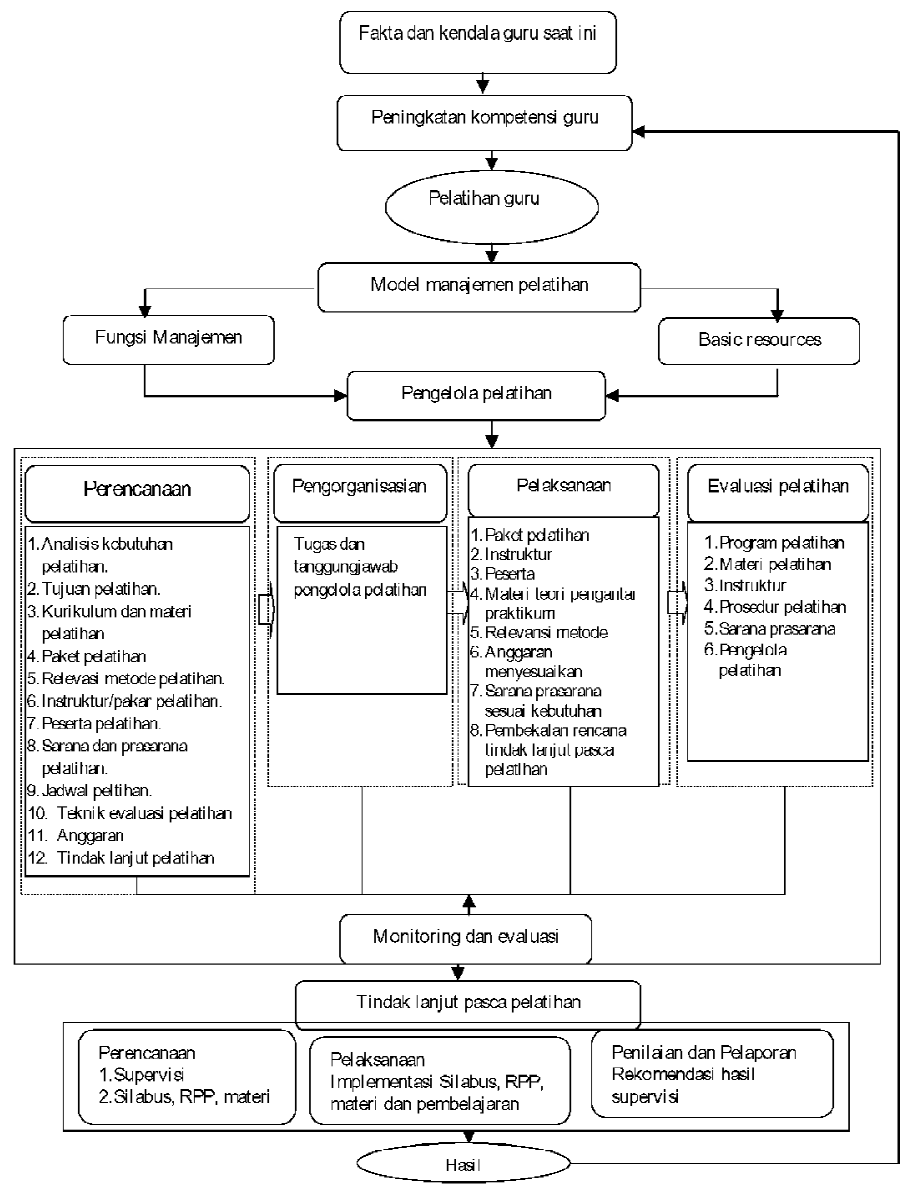

Gambar 1. Model Manajemen Pelatihan Alat Peraga Kontekstual 


\section{Metode Penelitian}

Jenis penelitian ini adalah penelitian kuantitatif. Populasi penelitian adalah seluruh guru IPA MI berbasis Pendidikan Agama Islam SeKecamatan Ngablak sejumlah delapan orang dengan ketentuan populasi dijadikan subyek penelitian semua. Penelitian ini diawali dengan studi pendahuluan untuk melakukan analisis kebutuhan, kenyataan pemanfaatan alat peraga IPA secara kontekstual, kendala dan minat pelatihan. Instrumen pengambilan data adalah angket dan interview untuk studi pendahuluan kebutuhan pelatihan dan alat peraga kontekstual. Soal pretes dan postes untuk mengetahui kemampuan awal dan akhir tentang alat peraga kontekstual. Lembar observasi untuk kepentingan data kemampuan pedagogik implementasi alat peraga kontekstual di lapangan pasca pelatihan. Angket evaluasi keberhasilan penyelenggaraan pelatihan. Data hasil studi pendahuluan tentang kenyataan pemanfaatan alat peraga IPA secara kontekstual, kendala dan minat pelatihan dianalisis dengan melakukan persentase. Dengan demikian dapat diketahui seberapa besar terhadap kenyataan pemanfaatan alat peraga IPA secara kontekstual, kendala dan minat pelatihan dari peserta. Untuk mengetahui efektifitas model manajemen pelatihan alat peraga IPA secara kontekstual berdasarkan disain pre-eksperimental dengan one group pretest-postest design.

$$
\begin{array}{|lll}
\mathrm{O}_{1} & \mathrm{X} & \mathrm{O}_{2} \\
\hline
\end{array}
$$

Gambar 2. Disain “One-Group Pretest-Posttest Design” (Sugiyono, 2009: 111)

Dimana $\mathrm{O}_{1}$ adalah nilai pretes (sebelum mengikuti pelatihan) sedangkan $\mathrm{O}_{2}$ adalah nilai postes (setelah mengikuti pelatihan). Dalam penelitian ini guru IPA MI berbasis Pendidikan Agama Islam sebelum mengikuti pelatihan alat peraga IPA diberikan pretes terlebih dahulu, kemudian peserta mengikuti pelatihan yaitu model manajemen pelatihan pemanfaatan alat peraga IPA secara kontekstual, setelah mengikuti pelatihan dilakukan postes. Dari data pretes dan postes yang telah diperoleh dilakukan uji t, jika data terdistribusi normal maka dilakukan uji parametrik (paried $t$ test), 
sedangkan jika data tidak terdistribusi secara normal maka dilakukan uji non parametrik (uji wilcoxon) menggunakan SPSS for windows 16. Untuk melihat efektifitas model manajemen pelatihan alat peraga secara kontekstual adalah hasil penilaian model manajemen pelatihan alat peraga IPA dari peserta dan hasil lembar observasi pascapelatihan.

\section{Analisis}

1. Kondisi nyata pemanfaatan alat peraga secara kontekstual melalui pemanfaatan alam sekitar pada guru IPA MI.

Berdasarkan angket dalam studi pendahuluan tentang kenyataan di lapangan, kendala dan minat serta kebutuhan pelatihan pemanfaatan alat peraga secara kontekstual melalui pemanfaatan alam sekitar dalam pembelajaran IPA diperoleh hasil seperti tabel 1, 2, 3 dan 4 .

Tabel 1

\section{Rekapitulasi hasil angket kondisi nyata dalam pemanfaatan alat peraga IPA secara kontekstual di MI se-Kecamatan Ngablak Jawa Tengah.}

\begin{tabular}{|c|c|c|c|c|c|c|}
\hline No & Pertanyaan & 1 & 2 & 3 & 4 & 5 \\
\hline 1 & $\begin{array}{l}\text { Pernahkah Bapak/Ibu melaksanakan } \\
\text { pembelajaran dengan pemanfaatan alat } \\
\text { peraga IPA di sekolah secara kontekstual? }\end{array}$ & $\begin{array}{c}7 \\
(87,5 \%)\end{array}$ & $\begin{array}{c}1 \\
(12,5 \%)\end{array}$ & $\overline{0}$ & $\overline{0}$ & 0 \\
\hline 2 & $\begin{array}{l}\text { Pernahkah Bapak/Ibu menemukan materi } \\
\text { dalam kurikulum IPA MI dapat disampaikan } \\
\text { dengan memanfaatkan alat peraga secara } \\
\text { kontektual? }\end{array}$ & 0 & $\begin{array}{c}8 \\
(100 \%)\end{array}$ & 0 & 0 & 0 \\
\hline 3 & $\begin{array}{l}\text { Pernahkah Bapak/Ibu sebagai guru IPA } \\
\text { berbasic Pendidikan Agama Islam, tidak } \\
\text { suka bila materi IPA disampaikan dengan } \\
\text { alat peraga? }\end{array}$ & $\begin{array}{c}1 \\
(12,5 \%)\end{array}$ & $\begin{array}{c}6 \\
(75 \%)\end{array}$ & 0 & $\begin{array}{c}1 \\
(12,5 \%)\end{array}$ & 0 \\
\hline
\end{tabular}

\section{Keterangan: (1) Tidak pernah, (2) Pernab, (3) Kadang- kadang, (4)Sering, (5)Sangat sering}

Dari rekapitulasi tabel 1 pada item 1, bahwa 87,5\% guru IPA MI berbasic Pendidikan Agama Islam di Kecamatan Ngablak belum melaksanakan pemanfaatan alat peraga IPA secara kontekstual melalui pemanfaatan alam sekitar. 75\% guru IPA MI berbasis Pendidikan Agama Islam tidak suka dalam pemanfaatan alat 
peraga dalam pembelajaran IPA. Berdasarkan kondisi nyata tersebut guru IPA MI berbasis Pendidikan Agama Islam sangat memerlukan solusi agar dapat memanfaatkan alat peraga dalam pembelajaran.

Tabel 2

\section{Rekapitulasi kendala pemanfaatan alat peraga IPA}

\begin{tabular}{|c|c|c|c|c|c|c|}
\hline $\mathrm{No}$ & Pertanyaan & 1 & 2 & 3 & 4 & 5 \\
\hline 1 & $\begin{array}{l}\text { Pernahkah Bapak/Ibu lebih menyukai } \\
\text { materi pelajaran IPA jika tidak } \\
\text { menggunakan alat peraga? }\end{array}$ & $\begin{array}{c}1 \\
(12,5 \% \\
)\end{array}$ & $\begin{array}{c}7 \\
(87,5 \%)\end{array}$ & 0 & $\overline{0}$ & $\overline{0}$ \\
\hline 2 & $\begin{array}{l}\text { Pernahkah Bapak/Ibu mengalami } \\
\text { kesulitan untuk menyampaikan materi } \\
\text { IPA dengan menggunakan alat peraga? }\end{array}$ & 0 & $\begin{array}{c}1 \\
(12,5 \%)\end{array}$ & 0 & 0 & $\begin{array}{c}7 \\
(87,5 \%)\end{array}$ \\
\hline 3 & $\begin{array}{l}\text { Pernahkah Bapak/Ibu mengalami } \\
\text { kesulitan dalam menemukan alat peraga } \\
\text { secara kontekstual? }\end{array}$ & 0 & 0 & 0 & $\begin{array}{c}8 \\
(100 \%)\end{array}$ & 0 \\
\hline
\end{tabular}

Keterangan: (1) Tidak pernab, (2) Pernah, (3) Kadangkadang, (4)Sering, (5)Sangat sering

Berdasarkan tabel 2, bahwa 87,5\% guru IPA MI se-Kecamatan Ngablak mengalami kesulitan menggunakan alat peraga IPA.

Tabel 3

\section{Rekapitulasi minat Guru IPA MI berbasis Pendidikan Agama Islam se-Kecamatan Ngablak dalam pelatihan pemanfaatan alat peraga}

\begin{tabular}{cllllllc}
\hline No & \multicolumn{2}{c}{ Pertanyaan } & 1 & 2 & 3 & 4 & 5 \\
\hline 1 & $\begin{array}{l}\text { Pernahkah } \\
\text { kompetensi profesional dalam memanfaatkan alat } \\
\text { peraga IPA secara kontektual? }\end{array}$ & & & & $(100 \%)$ & 0 \\
2 & $\begin{array}{l}\text { Pernahkah Bapak/Ibu berkeinginan mengikuti } \\
\text { pelatihan pemanfaatan alat peraga IPA secara } \\
\text { kontekstual? }\end{array}$
\end{tabular}

Keterangan: (1) Tidak pernah, (2) Pernab, (3) Kadangkadang, (4)Sering, (5)Sangat sering

Berdasarkan rekapitulasi angket minat guru IPA MI berbasis Pendidikan Agama Islam se-Kecamatan Ngablak dalam mengikuti pelatihan pemanfaatan alat peraga IPA secara kontekstual adalah sebesar $100 \%$. 
Tabel 4

\section{Rekapitulasi kebutuhan pelatihan pemanfaatan alat peraga IPA}

\begin{tabular}{|c|c|c|c|c|c|c|}
\hline $\mathrm{No}$ & Pertanyaan & 1 & 2 & 3 & 4 & 5 \\
\hline 1 & $\begin{array}{l}\text { Pernahkah Bapak/Ibu mengikuti sosialisasi pemanfaatan } \\
\text { alat peraga IPA? }\end{array}$ & $\begin{array}{c}8 \\
(100 \%)\end{array}$ & 0 & 0 & $\overline{0}$ & 0 \\
\hline 2 & $\begin{array}{l}\text { Pernahkah Bapak/Ibu mengikuti pelatihan pemanfaatan } \\
\text { alat peraga IPA? }\end{array}$ & $\begin{array}{c}8 \\
(100 \%)\end{array}$ & 0 & 0 & 0 & 0 \\
\hline 3 & $\begin{array}{l}\text { Pernahkah Bapak/Ibu merasa memerlukan pelatihan } \\
\text { pemanfaatan alat peraga IPA?. }\end{array}$ & 0 & 0 & 0 & $\begin{array}{c}8 \\
(100 \%)\end{array}$ & 0 \\
\hline 4 & $\begin{array}{l}\text { Pernahkah Bapak/Ibu berkeinginan mengikuti pelatihan } \\
\text { pemanfaatan alat peraga IPA? }\end{array}$ & 0 & 0 & 0 & 8 & 0 \\
\hline 5 & $\begin{array}{l}\text { Pernahkah Bapak/Ibu menemukan buku panduan } \\
\text { pemanfaatan alat peraga IPA secara kontekstual? }\end{array}$ & $\begin{array}{c}8 \\
(100 \%) \\
\end{array}$ & 0 & 0 & 0 & 0 \\
\hline
\end{tabular}

Keterangan: (1) Tidak pernah, (2) Pernab, (3) Kadangkadang, (4)Sering, (5)Sangat sering

Kebutuhan pelatihan dan pemanfaatan alat peraga IPA berdasarkan rekapitulasi tabel 4 adalah sebesar 100\%. Berdasarkan hasil rekapitulasi dan persentase pada tabel 1, 2, 3 dan 4 bahwa guru IPA MI berbasis Pendidikan Agama Islam se-Kecamatan Ngablak sangat membutuhkan pelatihan pemanfaatan alat peraga IPA.

2. Cara optimalisasi pemanfaatan alat peraga IPA secara kontekstual melalui pemanfaatan alam sekitar bagi guru IPA MI berbasis Pendidikan Agama Islam di Kecamatan Ngablak.

Berdasarkan kondisi nyata, kebutuhan, minat dan kendala seperti yang tertera dalam tabel 1, 2, 3 dan 4, maka perlu dilakukan langkah-langkah untuk peningkatan kompetensi pedagogik guru IPA MI berbasis Pendidikan Agama Islam dalam pemanfaatan alat peraga alam sekitar sebagai berikut: (1) pelatihan merupakan sebuah solusi untuk peningkatan kompetensi pedagogik guru IPA MI berbasis Pendidikan Agama Islam se-Kecamatan Ngablak, (2) perlu Fasilitator dalam pelatihan sesuai dengan kompetensi IPA, (3) perlu implementasi hasil pelatihan pasca pelatihan di lapangan, (4) perlu supervisor untuk mengamati implementasi hasil pelatihan pasca pelatihan di lapangan.

3. Efektifitas model manajemen pelatihan alat peraga secara kontekstual melalui pemanfaatan alam sekitar dalam peningkatan 
kompetensi pedagogik guru IPA MI berbasis Pendidikan Agama Islam di Kec. Ngablak.

Hasil penelitian menunjukkan bahwa model manajemen pelatihan alat peraga IPA secara kontekstual bagi guru IPA MI berbasis Pendidikan Agama Islam se-Kecamatan Ngablak efektif dapat meningkatkan kemampuan pedagogik guru IPA MI tersebut. Rincian hasil penelitian yang menunjukkan efektifitas model manajemen pelatihan alat peraga IPA secara kontekstual adalah:

a. Hasil penilaian model manajemen pelatihan alat peraga IPA. Hasil penilaian peserta dari implementasi model manajemen pelatihan alat peraga IPA bagi guru IPA MI berbasis Pendidikan Agama Islam adalah masuk kategori sangat baik dengan komponen materi rerata: 4.38, instruktur rerata: (4.36), progam rerata: 4.34, prosedur rerata (4.36), sarana dan prasarana dan komsumsi (4.55).

b. Hasil pretes dan postes peserta pelatihan

Efektifitas dari model manajemen pelatihan alat peraga IPA dapat ditunjukkan adanya peningkatan kemampuan awal (pretes) dibandingan dengan kemampuan akhir (postes) bagi peserta.

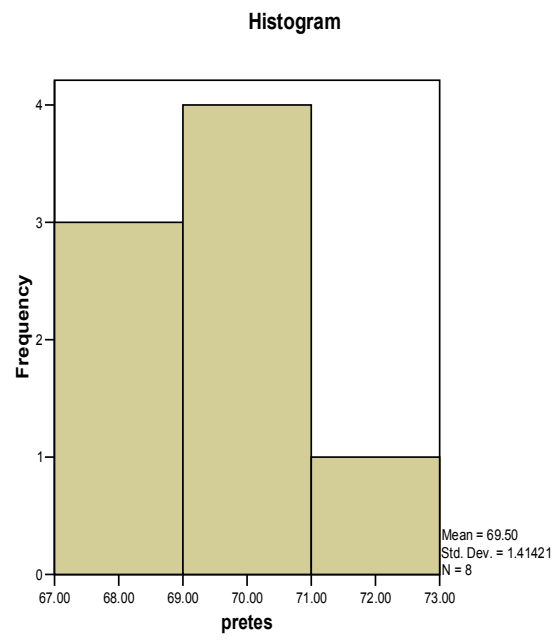

Gambar 3. Rata-rata dan Standar Deviasi dari nilai pretes dan postes. 


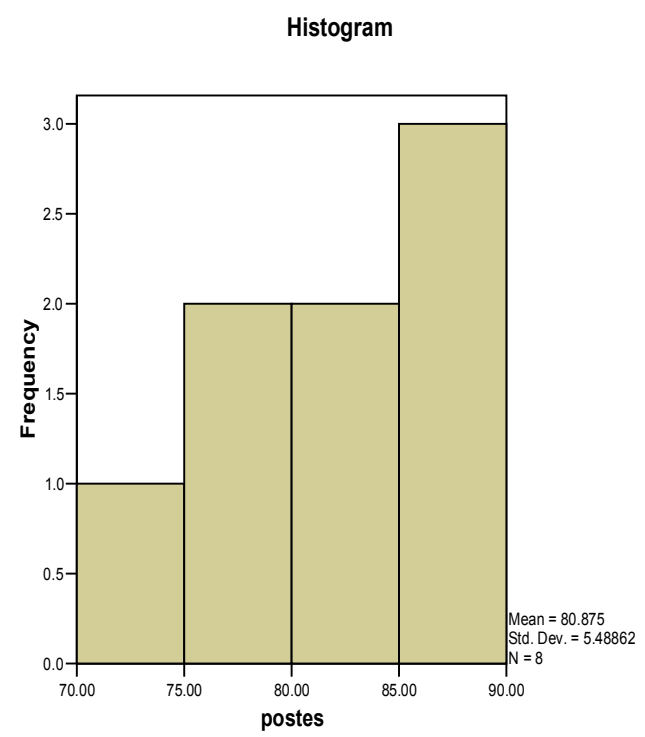

Gambar 4. Rata-rata dan Standar Deviasi dari nilai pretes dan postes.

Berdasarkan gambar 3 dan gambar 4 rata-rata pretes peserta 69,50 dan rata-rata postes 80,87 . Rata-rata tersebut menunjukkan terdapat peningkatan yang sangat signifikan $(11,37)$. Hal tersebut menunjukkan bahwa model manajemen pelatihan alat peraga dapat meningkatkan kemampuan pedagogik guru IPA MI berbasis Pendidikan Agama Islam se-Kecamatan Nagblak Kabupaten Magelang.

Untuk membandingkan hasil pretes terhadap postes dari peserta maka terlebih dahulu dilakukan uji normalitas data. Hasil normalitas data adalah seperti pada tabel 5.

$$
\text { Tabel } 5
$$

\section{Hasil Uji Normalitas Data}

\begin{tabular}{|l|r|r|r|}
\hline & \multicolumn{3}{|c|}{ Shapiro-Wilk } \\
\hline & Statistic & Df & Sig. \\
\hline Pretes & 0.827 & 8 & 0.056 \\
Postes & 0.959 & 8 & 0.796 \\
\hline
\end{tabular}


Berdasarkan tabel 5 diperoleh hasil pretes dengan signifikasi 0,056 > 0,05 dan postes dengan signifikansi 0,796 > 0,05. Kesimpulan bahwa data hasil pretes dan postes terdistribusi secara normal. Untuk melihat perbedaan hasil pretes terhadap postes dilakukan dilakukan uji paired $t$ test seperti pada tabel 6.

Tabel 6

\section{Hasil Paired t Test}

\begin{tabular}{|c|c|c|c|c|c|c|c|c|}
\hline & \multicolumn{5}{|c|}{ Paired Differences } & \multirow[t]{2}{*}{$\mathrm{T}$} & \multirow[t]{2}{*}{ Df } & \multirow[t]{2}{*}{$\begin{array}{l}\text { Sig. (2- } \\
\text { tailed) }\end{array}$} \\
\hline & Mean & $\begin{array}{c}\text { Std. } \\
\text { Deviation }\end{array}$ & $\begin{array}{l}\text { Std. Error } \\
\text { Mean }\end{array}$ & $\begin{array}{l}95 \% \mathrm{Cc} \\
\text { Interv } \\
\text { Diff }\end{array}$ & $\begin{array}{l}\text { idence } \\
\text { of the } \\
\text { nce }\end{array}$ & & & \\
\hline & & & & Lower & Upper & & & \\
\hline $\begin{array}{ll}\text { Pair 1 } & \begin{array}{l}\text { pretes - } \\
\text { postes }\end{array}\end{array}$ & -11.37500 & 4.43807 & 1.56909 & -15.08532 & -7.66468 & -7.249 & 7 & 0.000 \\
\hline
\end{tabular}

Berdasarkan hasil paired $t$ test maka diperoleh hasil signifikansi $0,000<0,05$, dengan demikian dapat diambil kesimpulan bahwa terdapat perbedaan antara hasil pretes dengan postes.

c. Hasil observasi kemampuan pedagogik pascapelatihan

Bukti efektifitas model manajemen pelatihan alat peraga IPA yang lain adalah dari hasil observasi implementasi pascapelatihan alat peraga di sekolah masing-masing peserta. Adapun hasil observasi pada tabel 7. Berdasarkan hasil observasi pada tabel 7, guru IPA MI berbasis Pendidikan Agama Islam kompeten dalam implementasi kemampuan pedagogik melalui penggunaan alat peraga IPA di Sekolah. Hal tersebut menunjukkan bahwa model manajemen pelatihan alat peraga IPA efektif dapat meningkatkan kemampuan pedagogik guru IPA MI berbasis Pendidikan Agama Islam. 


\section{Tabel 7}

\section{Hasil observasi Implementasi Kompetensi pedagogi pasca pelatihan alat peraga IPA di sekolah}

\begin{tabular}{|c|c|c|}
\hline Indikator & $\begin{array}{c}\text { Rata-rata } \\
\text { skor }\end{array}$ & Kategori \\
\hline $\begin{array}{l}\text { Pemetaan Standar Kompetensi dan Kompetensi Dasar } \\
\text { materi IPA terpadu yang berpotensi untuk }\end{array}$ & 4.00 & $\begin{array}{l}\text { Sangat } \\
\text { Kompeten }\end{array}$ \\
\hline $\begin{array}{l}\text { disampaikan dengan alat peraga secara kontekstual } \\
\text { Silabus dan RPP materi IPA terpadu yang berpotensi } \\
\text { untuk disampaikan dengan alat peraga secara } \\
\text { kontekstual }\end{array}$ & 3.00 & Kompeten \\
\hline $\begin{array}{l}\text { Persiapan pembuatan alat evaluasi sehubungan } \\
\text { dengan alat peraga kontekstual }\end{array}$ & 3.00 & Kompeten \\
\hline $\begin{array}{l}\text { Persiapan metode pembelajaran yang digunakan } \\
\text { dalam pembelajaran IPA dengan alat peraga } \\
\text { kontekstual }\end{array}$ & 3.00 & Kompeten \\
\hline $\begin{array}{l}\text { Persiapan alat peraga kontekstual dalam pembelajaran } \\
\text { IPA }\end{array}$ & 3.00 & Kompeten \\
\hline Persiapan sumber belajar kontekstual & 3.00 & Kompeten \\
\hline $\begin{array}{l}\text { Kemampuan melakukan motivasi, apersepsi materi } \\
\text { yang berpotensi dalam pembelajaran IPA dengan alat } \\
\text { peraga kontekstual }\end{array}$ & 3.00 & Kompeten \\
\hline $\begin{array}{l}\text { Kemampuan melakukan penyampaian materi IPA } \\
\text { sesuai dengan silabus dan RPP dengan menggunakan } \\
\text { alat peraga kontekstual }\end{array}$ & 3.00 & Kompeten \\
\hline $\begin{array}{l}\text { Kemampuan menggunakan alat peraga kontekstual } \\
\text { dalam penyampaian materi IPA }\end{array}$ & 3.00 & Kompeten \\
\hline $\begin{array}{l}\text { Kemampuan menggunakan variasi alat peraga } \\
\text { kontekstual dalam pembelajaran IPA }\end{array}$ & 3.00 & Kompeten \\
\hline $\begin{array}{l}\text { Kemampuan membuat alat evaluasi materi IPA dengan } \\
\text { menggunakan alat peraga kontekstual }\end{array}$ & 3.00 & Kompeten \\
\hline $\begin{array}{l}\text { Kemampuan melakukan inovasi alat peraga } \\
\text { kontekstual }\end{array}$ & 3.00 & Kompeten \\
\hline $\begin{array}{l}\text { Kesesuaian alat evaluasi dengan silabus dan RPP } \\
\text { materi IPA dengan menggunakan alat peraga } \\
\text { kontekstual }\end{array}$ & 3.00 & Kompeten \\
\hline $\begin{array}{l}\text { Kesesuaian jumlah soal dengan waktu yang } \\
\text { dialokasikan }\end{array}$ & 3.00 & Kompeten \\
\hline $\begin{array}{l}\text { Kesesuaian distribusi soal dengan cakupan materi } \\
\text { dalam silabus dan RPP materi IPA dengan } \\
\text { menggunakan alat peraga kontekstual }\end{array}$ & 3.00 & Kompeten \\
\hline
\end{tabular}

\section{Analisis}

Berdasarkan angket dalam studi pendahuluan tentang kenyataan di lapangan 87,5\% guru IPA MI berbasis Pendidikan Agama Islam di Kecamatan Ngablak belum melaksanakan pemanfaatan alat 
peraga IPA secara kontekstual melalui pemanfaatan alam sekitar. 75\% guru IPA MI berbasis Pendidikan Agama Islam tidak suka dalam pemanfaatan alat peraga dalam pembelajaran IPA. Berdasarkan kondisi nyata tersebut guru IPA MI berbasis Pendidikan Agama Islam sangat memerlukan solusi agar dapat memanfaatkan alat peraga dalam pembelajaran, agar pembelajaran IPA dapat lebih bermakna. Berdasarkan kendala pemanfaatan alat peraga dalam pembelajaran IPA bahwa 87,5\% guru IPA MI berbasis Pendidikan Agama Islam se-Kecamatan Ngablak mengalami kesulitan dalam menyampaikan materi IPA dengan menggunakan alat peraga.

Pada sisi lain apabila kita cermati secara seksama bahwa alam semesta merupakan sumber belajar yang dapat dimanfaatkan sebagai modal dalam membuat alat peraga IPA. Alam semesta dengan segala isinya adalah anugrah yang merupakan tanda-tanda kebesaran Allah SWT. QS. Ali Imran:190-191 yang mengandung arti:

Sesungguhnya dalam penciptaan langit dan bumi, dan silih bergantinya malam dan siang terdapat tanda-tanda bagi orang-orang yang berakal, (yaitu) orang-orang yang mengingat Allah sambil berdiri atau duduk atau dalam keadaan berbaring dan mereka memikirkan tentang penciptaan langit dan bumi (seraya berkata): "Ya Tuhan kami, tiadalah Engkau menciptakan Ini dengan sia-sia, Maha Suci Engkau, Maka peliharalah kami dari siksa neraka .

Al qur'an Surat Ali Imran: 190-191 dapat dijadikan pedoman bahwa alam semesta terdapat sesuatu untuk dipelajari dan dipikirkan. Allah SWT telah menciptakan dunia ini dengan sempurna sebagai rahmat yang diturunkan-Nya kepada manusia, tinggal bagaimana manusia memanfaatkannya. Contoh konkret adalah alam dapat dijadikan sebagai modal dalam pembelajaran secara kontekstual. Alat peraga yang dapat diambil dari alam juga tersedia apabila guru pandai dalam memanfaatkannya.

Berdasarkan angket minat guru IPA MI berbasis Pendidikan Agama Islam se-Kecamatan Ngablak dalam mengikuti pelatihan pemanfaatan alat peraga IPA secara kontekstual adalah sebesar 100\%. Kebutuhan pelatihan dan pemanfaatan alat peraga IPA berdasarkan rekapitulasi tabel 4 adalah sebesar 100\%. Berdasarkan hasil rekapitulasi dan persentase pada tabel 1, 2, 3 dan 4 bahwa 
guru IPA MI berbasis Pendidikan Agama Islam se-Kecamatan Ngablak sangat membutuhkan pelatihan pemanfaatan alat peraga IPA. Berdasarkan fakta di atas maka guru IPA MI berbasic Pendidikan Agama Islam memerlukan pelatihan alat peraga IPA secara kontekstual. Dengan pelatihan akan dapat memberikan pengalaman langsung dan dapat meningkatkan kemampuan seseorang. Senada dengan Notoatmodjo (2009: 16) menyatakan bahwa "Pelatihan adalah bagian dari suatu proses pendidikan, yang tujuannya untuk meningkatkan kemampuan atau keterampilan khusus seseorang atau kelompok organisasi".

Cara optimalisasi pemanfaatan alat peraga IPA secara kontekstual bagi guru IPA MI berbasis Pendidikan Agama Islam di Kecamatan Ngablak adalah sebagai berikut: (1) pelatihan merupakan sebuah solusi untuk peningkatan kompetensi pedagogik guru IPA MI berbasis Pendidikan Agama Islam se-Kecamatan Ngablak, (2) perlu Fasilitator dalam pelatihan sesuai dengan kompetensi IPA, (3) perlu implementasi hasil pelatihan pasca pelatihan di lapangan, (4) perlu supervisor untuk mengamati implementasi hasil pelatihan pasca pelatihan di lapangan.

Efektifitas model manajemen pelatihan alat peraga secara kontekstual dalam peningkatan kompetensi pedagogik guru IPA MI berbasis Pendidikan Agama Islam di Kecamatan Ngablak Kabupaten Magelang. Efektifitas model manajemen pelatihan alat peraga secara kontekstual melalui pemanfaatan alam sekitar dapat ditunjukkan pada: (1) Hasil penilaian model manajemen pelatihan alat peraga IPA secara kontekstual oleh peserta dengan kategori sangat baik dari setiap unsur model manajemen, (2) peningkatan kemampuan pretes dan postes peserta, paired t test diperoleh hasil signifikansi $0,000<0,05$, dengan demikian dapat diambil kesimpulan bahwa terdapat perbedaan antara hasil pretes dengan postes., (3) hasil pengamatan kemampuan penggunaan alat peraga IPA peserta pascapelatihan di sekolah masing-masing dengan hasil kompeten.

Model manajemen pelatihan alat peraga IPA efektif dapat meningkatkan kemampuan pedagogik guru IPA MI berbasis Pendidikan Agama Islam se- Kecamatan Ngablak Kabupaten Magelang, hal tersebut karena pelatihan dilakukan berdasarkan analisis kebutuhan dan manajemen pelatihan yang profesional. Hal 
tersebut senada dengan Mulyono (2009: 18), (Fatah: 2009: 1), Kamil (2010: 16) menyatakan "manajemen adalah sebuah proses yang khas yang terdiri dari perencanaan, pengorganisasian, penggerakan dan pengawasan serta evaluasi yang dilakukan pihak pengelola organisasi untuk mencapai tujuan bersama dengan memberdayakan sumber daya lainnya secara efektif dan efesien". Efektifitas model manajemen pelatihan alat peraga IPA sesuai dengan pendapat Mujiman (2009: v) manajemen pelatiban adalab "pengelolaan program pelatiban, yang menyangkut aspek pengidentifikasian kebutuban pelatihan, perencanaan disain pelatihan, penetapan metodologi pelatihan, penyusunan bahan pelatihan, pelaksanaan pelatihan, evaluasi pelatiban, dan penetapan tindak lanjut pelatiban". Untuk mencapai tujuan dari manajemen pelatihan yang dilakukan, diperlukan sarana-sarana atau unsur-unsur manajemen.

\section{Kesimpulan}

Kondisi nyata pemanfaatan alat peraga secara kontekstual dari alam sekitar pada guru IPA MI berbasis Pendidikan Agama Islam di Kecamatan Ngablak Kabupaten Magelang adalah 87,5\% guru IPA MI mengalami kesulitan dan belum melaksanakan pemanfaatan alat peraga IPA secara kontekstual dari alam sekitar, 75\% guru IPA MI tidak suka dalam pemanfaatan alat peraga IPA. 100\% guru IPA MI membutuhkan dan berminat mengikuti pelatihan pemanfaatan alat peraga IPA secara kontekstual melalui pemanfatan alam sekitar.

Cara optimalisasi pemanfaatan alat peraga IPA secara kontekstual melalui pemanfatan alam sekitar bagi guru IPA MI berbasis Pendidikan Agama Islam di Kecamatan Ngablak adalah sebagai berikut: pelatihan merupakan sebuah solusi untuk peningkatan kompetensi pedagogik guru IPA MI berbasis Pendidikan Agama Islam se-Kecamatan ngablak, perlu fasilitator dalam pelatihan sesuai dengan kompetensi IPA, perlu implementasi hasil pelatihan pasca pelatihan di lapangan, perlu supervisor untuk mengamati implementasi hasil pelatihan pasca pelatihan di lapangan.

Model manajemen pelatihan alat peraga secara kontekstual melalui pemanfaatan alam sekitar efektif dapat meningkatan kompetensi pedagogik guru IPA MI berbasis Pendidikan Agama Islam 
di Kecamatan Ngablak Kabupaten Magelang. Efektifitas model manajemen pelatihan alat peraga secara kontekstual dapat ditunjukkan pada: (1) Hasil penilaian model manajemen pelatihan alat peraga IPA secara kontekstual oleh peserta dengan kategori sangat baik dari setiap unsur model manajemen, (2) peningkatan kemampuan pretes dan postes peserta, paired t test diperoleh hasil signifikansi $0,000<0,05$, dengan demikian dapat diambil kesimpulan bahwa terdapat perbedaan antara hasil pretes dengan postes., (3) hasil pengamatan kemampuan penggunaan alat peraga IPA peserta pascapelatihan di sekolah masing-masing dengan hasil kompeten.

\section{Daftar Pustaka}

Danso, H., Adu, M. K., Twum-Ampomah, M. K., dan Mrah, R. K. 2012. "Evaluation of In-Service Training for Senior Staff of a Public University in Ghana". Journal of Education and Practice. 2222-1735, 3 (7): 96-104.

Fattah, Nanang. 2009. Landasan Manajemen Pendidikan. Bandung: Remaja Rosda Karya.

Hanrahmawan, F. 2010. Revitalisasi Manajemen Pelatihan Tenaga Kerja (Studi Kasus Pada Balai Latihan Kerja Industri Makassar). Jurnal Administrasi Publik. 1 (1): 78-94.

Ian. 2010. Perbedaan Media dan Alat Peraga. http://ian43. wordpress.com/2010/11/03/ perbedaan-media-dan-alatperaga/\#more-754. Diunduh pada tanggal 15 Maret 2013.

Kamil, M. 2010. Model Pendidikan dan Pelatihan (Konsep dan Aplikasi). Bandung: Alfabeta.

Kunandar. 2011. Guru Profesional Implementasi Kurikulum Tingkat Satuan Pendidikan (KTSP) dan Sukses dalam Sertifikasi Guru. Jakarta: Rajawali Pers.

Mahmuddin. 2008. Kompetensi Pedagogik Guru Indonesia. http:// mahmuddin. wordpress.com /2008/03/19/kompetensi-pedagogik-guru-indonesia/. Diunduh pada tanggal 13 Maret 2013.

Mujiman, H. 2009. Manajemen Pelatihan Berbasis Belajar Mandiri. Jogjakarta: Pustaka Pelajar Offset.

Mulyono. 2009. Manajemen Administrasi dan Organisasi Pendidikan. Jogjakarta: Ar-Ruzz Media.. 
Moeini, Hosein. 2008. "Identifying Needs: A Missing Part in Teacher Training Programs". International journal of media, technology and lifelong learning. 4 (1): $1-12$.

Notoatmodjo, S. 2009. Pengembangan Sumber Daya Manusia. Cetakan ke-4. Jakarta: Rineka Cipta.

Nuryati. 2014. Manfaat Alat Peraga dalam Proses Pembelajaran IPA. http://sultengpost.com /blog/2014/04/21/manfaat-alat-peragadalam-proses-pembelajaran-ipa/

Osunde and Omoruyi . 2004. "An Evaluation of the National Teachers Institute's Manpower Training Program for Teaching Personnel in Mid-western Nigeria Faculty Of Education, University of Benin, Nigeria”. International Education Journal. 5 (3): 405 - 409.

Saputro, B. 2013. Pengemgembangan Model Manajemen Pelatihan IPA Terpadu dalam Rangka Peningkatan Kemampuan Profesional bagi Guru IPA SMP Se-Kabupaten Kudus. Disertasi. UNNES Semarang.

Sedarmayanti. 2010. Manajemen Sumber Daya Manusia Reformasi Birokrasi dan Manajemen Pegawai Negeri Sipil. Bandung: Refika Aditama.

Sudjana, N. 2002. Dasar-dasar Proses Belajar Mengajar. Bandung: Sinar Baru Algensindo.

Sugiyono. 2009. Metode Penelitian Pendidikan (Pendekatan Kuantitatif, Kualitatif dan $R \in D D$ ). Bandung: Alfabeta.

Susanti, I., Hubeis, A. V., dan Kuswanto, S. 2012. "Perancangan Manajemen Kinerja Penyelenggaraan Pendidikan dan Pelatihan dengan Rancangan Management By Objectives (MBO) dan Perspektif Balanced Scorecard". Jurnal Manajemen \& Agribisnis. 1693-5853. 9 (1): 43-58.

Terry, G. R. 1977. Principles of Management. $7^{\text {rd }}$ ed. United State of America: Illionis Richard D. Irwin, Inc

Undang-Undang No. 14 Tahun 2005 tentang Guru dan Dosen. 2010. Jakarta: Diperbanyak oleh Sinar Grafika.

Uno, H. B. 2010. Profesi Kependidikan Problema, Solusi, dan Reformasi Pendidikan di Indonesia. Jakarta: Bumi Aksara.

Wibowo. 2010. Manajemen Kinerja Edisi Ketiga. Jakarta: Rajawali Press. 